\title{
Organizational Behavior in Innovation, Marketing, and Purchasing in Business Service Contexts-An Agenda for Academic Inquiry
}

Maria Holmlund (corresponding author)*, Christian Kowalkowski**** and Sergio Biggemann***

* Department of Marketing, CERS - Centre for Relationship Marketing and Service Management, Hanken School of Economics, Helsinki, PO Box 479, FI-00101 Helsinki, Finland. Tel +358 403521 396, maria.holmlund-rytkonen@hanken.fi

** Department of Management and Engineering, Linköping University, SE-581 83 Linköping, Sweden.

*** Marketing Department, School of Business, University of Otago, PO Box 56, Dunedin 9054, New Zealand.

Original Publication:

Holmlund, M., Kowalkowski, C. and Biggemann, S. (2016), “Organizational Behavior in Innovation, Marketing, and Purchasing in Business Service Contexts-An Agenda for Academic Inquiry", Journal of Business Research, Vol. 69.

http://dx.doi.org/10.1016/j.jbusres.2016.02.014

Copyright: Elsevier

http://www.elsevier.com 


\begin{abstract}
Many businesses today recognize the increased significance of service and the transition toward service orientation. Nonetheless, organizational practitioners frequently encounter problems managing this shift and seizing service-related business opportunities. This practical relevance, together with many still-unanswered service research questions, have inspired the preparation of this special section. We discuss the significance of business services from an academic and practitioner perspective. We find ample opportunities for conducting research combining managerial and academic relevance on behavioral theory linked to innovation, marketing, and purchasing research in business-to-business service contexts. The interrelationships among these domains are ripe for theoretical and empirical development. Against this background, the contributions in this special issue advance the extant literatures on business services and include (1) a study on how incremental innovation can become tradable as a service, (2) a demonstration of how innovative brands increases business performance, (3) a behavioral approach on organizational innovation adoption, (4) a framework of how practitioners handle relationship gaps and what factors form their behaviors, (5) an analysis of the role of relationship learning between service offerings and sales performance, and (6) an investigation of how power relationships and social integration influence learning in temporary organizations. We finish by providing a research agenda. First, more research is needed on the buyer perspective. Second, researchers need to keep in mind financial issues related to business services. Third, more researchers could tap into management, leadership, and decision-making in business service companies. Finally, sustainability, social responsibility, and environmental considerations are important topics for further exploration.
\end{abstract}


Keywords: Business-to-business services, industrial service, service marketing, service innovation, service purchasing, research agenda

\section{Highlights:}

- Business services constitute a fruitful area for merging research with theoretical rigor and managerial relevance.

- Aligning innovation, marketing, and purchasing is becoming increasingly important, as firms and networks strive to offer industrial services and other business services.

- The selected studies represent a combination of qualitative and quantitative methodologies and empirical and conceptual research.

- The research agenda advocates new ideas related to the buyer perspective, financial issues, leadership issues, and sustainability. 


\section{Organizational Behavior in Innovation, Marketing, and Purchasing in Business Service Contexts-An Agenda for Academic inquiry}

\section{Introduction}

Services are the fastest growing sector in industrial economies; firms and scholars are replacing product-driven business logic with service-oriented logic as the focus of business shifts toward greater interactivity and facilitation of value creation processes (Grönroos \& Voima, 2013; Vargo \& Lusch, 2004). As Wirtz, Tuzovic, and Ehret (2015) show, business services (including industrial services) explain a large share of the growth of the global service economy. Many reasons for this steady growth trend have been observed. For example, Sheth, Sharma, and Iyer (2009) identified some drivers that promote this development: intensified competition that calls for new service-oriented means of competition, increased willingness to source services and products from other firms, more diverse industrial companies, globalized buyers with more centralized purchasing and a shift from product purchasing to solution purchasing, and decreased transactional costs and new services using information and communication technologies. As a consequence, developing, marketing, and buying services as well as operating in a serviceoriented manner instead of focusing on manufacturing and tangible goods have become essential for most industrial firms.

\subsection{Academic Interest in Business Services}

Against this background, this special issue focuses on the business service context. This context encompasses firms and networks in both manufacturing and service industries and 
includes industrial services, logistics and distribution services, R\&D and design services, support services, integrated solutions, and other knowledge-intensive business services that organizations in the private and public sector purchase. There are many motives to research this context, which has received comparatively less attention than, for example, consumer services. Some of these reasons are academic and based on an aim to increase the understanding of different issues related to business services. For example, the recent award-winning global research priority article authored by Ostrom, Parasuraman, Bowen, Patrício, Voss, and Lemon (2015) lists topics such as developing service networks and systems, service infusion, solutions, and servitization as well as sub-topics such as changing organizational cultures to support servitization and identifying the leadership competencies that are critical for managing such services. Later, in the section entitled "An Agenda for Academic Inquiry," we present further ideas for topics that need more attention.

In addition to some scientific journals regularly publishing papers on different issues related to business services, a few journal issues have been dedicated to innovation, marketing, and purchasing and the integration of these in the business service sector. Taking a business-tobusiness but not specifically a business service perspective, Industrial Marketing Management has published related special issues on the following themes: Organizing and Integrating Marketing and Purchasing in Business Markets (Ivens, Pardo, \& Tunisini, 2009), Comanagement of Purchasing and Marketing (Lindgreen, Campelo, \& Angell, in press), and Implementing Strategies and Theories of B2B Marketing and Sales Management (Möller \& Parvinen, 2015). Combining a manufacturing with a service focus but not highlighting innovation, marketing, or purchasing, the Journal of Service Management has published special issues on Service Infusion in Manufacturing Industries (Gustafsson, Brax, \& Witell, 2010) and 
the Management of Complex Engineering Service Systems (Neely, Ng, \& Roy, 2014). Industrial Marketing Management highlighted service systems/science and creativity in business services in another special issue, entitled B2B Service Networks and Managing Creativity in Business Market Relationships (Henneberg, Gruber, \& Naudé, 2013) In the Journal of Business Research, a similar special issue (but without a service focus) has been published, entitled Winning Strategies for Innovation and High-Technology Products Management (Kim \& Huarng, 2011), and the Journal of Business \& Industrial Marketing has had a special issue specifically on Service Innovation in B2B Firms (Kindström \& Kowalkowski, 2014). However, no previous special issue has combined three fundamental business functions with a business service context. This special issue is thus a response to this gap and the call for more research transcending the functional borders specifically in the service setting.

\subsection{Company Relevance of Business Services}

For us, a significant justification for paying special attention to business services is the managerial perspective. Although product-centric firms may today acknowledge the significance of service and the transition toward services, many struggle to envision how they would best manage the process in practice because an increased service orientation often involves a major shift to a new strategic direction, a new organizational structure, and new skills (e.g., Gebauer, Gustafsson, \& Witell, 2011; Jacob and Ulaga, 2008; Kowalkowski, Kindström, Brashear, Brege, \& Biggemann, 2012). In manufacturing sectors, the managerial challenges are further amplified by the "service paradox" (Gebauer, Fleisch, \& Friedli, 2005); many industrial firms who invest heavily in growing their service business do not seem to achieve the competitive and financial benefits that they expected. 
The issue of relevance of marketing research is increasingly debated, although there seems to be a clear consensus that marketing as a field of study is closely allied to the practice of marketing and that academic interest, therefore, should stay close to company practice and concerns (Brennan, Tzempelikos, \& Wilson, 2014; Jaworski, 2011; Piercy, 2002). Kowalkowski (2015) argues that "Too much research in marketing focuses on narrow methodological issues and esoteric phenomena detached from the reality of the business world" (p. 55). Furthermore, Yadav (2010), after examining academic articles, even concluded that conceptual articles could make at least as great a contribution to marketing practice as do empirical articles.

The reasons for academic research not being sufficiently close to practice are many, including researcher attitude and lack of experience as well as insufficient contact forums between researchers and managers, and they refer to all phases of the research project, from idea forming to recommendation presentation. Nevertheless, in line with service scholars Gustafsson, Aksoy, Brady, McColl-Kennedy, Sirianni, Witell, \& Wuenderlich (2015), we also believe that the service contexts constitute particularly fruitful areas for merging research with theoretical rigor and managerial relevance. One reason for a low threshold of combining academic and managerial interests is that business service research can be considered to be rather multidisciplinary and applied in that it addresses specific managerial issues. A second reason is that researchers should be able to relatively easily get acquainted with company managers, engage in consulting/training assignments, and expose themselves to practical managerial problems. The potential to create mutually truly beneficial new knowledge would function as the driver and inspiration for these endeavors. In addition, business service research can fit very well with the engaged scholarship concept (Van de Ven, 2007), which is a participative form of research for obtaining the views of key stakeholders to understand a complex problem and 
produce knowledge that is more penetrating and insightful than is produced when researchers work alone.

\subsection{Innovation, Marketing, and Purchasing}

Innovation, marketing, and purchasing (both service sourcing and customer buying behavior) play key roles for successful service management and service-led growth. However, much remains to be done to understand how to manage intrafirm and interfirm collaboration efforts among these three functions. Organizational practitioners may understand the importance of co-managing the interfaces and achieving fit between the functions but lack tools and frameworks to turn theory into practice. The significance of organizational learning and relationship-building practices for service operations (Grönroos \& Ojasalo, 2004) and the increasing dependence of service partners and specialist suppliers to meet ever more complex customer demands (Ostrom et al., 2015) makes these issues particularly relevant and timely.

We agree with Wiersema (2013), who contends that innovation and marketing must not be separate islands. A strong innovation-marketing interface facilitates coordination between development and commercialization processes, and marketing can pave the way for customeroriented service innovation initiatives. Such innovation addresses buyer needs beyond the product, so marketing has to interpret customers' overall value perceptions and understand how buyers make buying decisions for these extensive offerings. The increase in complexity also requires greater coordination efforts and a changed mindset and culture (Wiersema, 2013).

More interfirm collaboration is demanded for such "beyond-the-lab" innovations, and customers serve as a particularly important component (Kindström, Kowalkowski, \& Sandberg, 2013); as Ngo and O'Cass (2013) demonstrate, customer participation in service innovation can 
have positive effects on future service quality. Similarly, Sheth and colleagues (2009) call for a stronger alignment of purchasing with marketing, which would facilitate service innovation and enable the development of tailor-made solutions. To be successful, purchasing should be less connected to production and operations; purchasing's new role would involve being an outsourcing coordinator, putting together services contracted from various vendors to arrange the best overall solution developed in interaction between marketing and the customer. In terms of internal coordination, Wagner and Eggert (in press) suggest that joint management of marketing and purchasing allows a firm to accommodate dependence on critical upstream and downstream resources within the network.

Clearly, aligning innovation, marketing, and purchasing is becoming increasingly important, as individual firms as well as interfirm value constellations in service networks strive to offer industrial services and other business services. Following Cyert and March (1963), organizations can be viewed as coalitions of stakeholders, with coalition members representing individuals and groups from innovation, marketing, and purchasing as well as suppliers, customers, and other partners. The organizational goals must deal successfully with the potential goal conflicts inherent in such coalitions. Furthermore, business services span a wide range of offerings - from various product-oriented and process-oriented services and service bundles to hybrid product-service offerings (Ulaga \& Reinartz, 2011) and integrated solutions (Davies, 2004), which are sold based on usage or functional results. Hence, different types of services have different prerequisites; depending on what services are developed and offered, different organizational routines might need to be in focus. More research is needed on the actual process of organizational decision-making in the business service context. This need is particularly great given the high failure rate of new market launches, such as new industrial service initiatives (cf. 
Ulaga \& Reinartz, 2011). Factors in this failure include the path dependence of routines and incumbent inertia, whereas root causes, according to Lieberman and Montgomery (1988), include being locked in to a specific set of fixed assets, reluctance to cannibalize existing offerings, and organizational inflexibility.

\section{Contributions to This Special Section}

In light of the diversity of organizations and networks providing business services, the diversity of service offerings, and the traditional dichotomy between innovation, marketing, and purchasing, we view the studies of organizational behavior for innovation, marketing, and purchasing in a business service context to be critical topics for further investigation. Therefore, it is an opportune time to seek to publish articles that critically engage with these research topics.

As guest editors we invited articles with an original perspective and advanced thinking on behavioral theory linked to innovation, marketing, and purchasing research in business-tobusiness service contexts. To present leading thought and practices related to these issues, this special section features six articles that were selected via a blind triple reviewer and multirevision round process of 28 originally submitted manuscripts. The first three contributions explicitly deal with one or more of the three focuses of analysis (innovation, marketing, purchasing) whereas the remaining three articles study relationship management or organizational learning. In the following we show a simple analytical framework to categorize research about business services and make a distinction according to whether the fundamental level of analysis is primarily the seller, the relationship, or the buyer. Different potential research arenas can accordingly be distinguished; Figure 1 combines these levels with the focuses in this special section (innovation, marketing, and purchasing). Our original intention was not to 
systematically cover the categories, and the selected papers are slightly dominated by a seller level of analysis with a marketing issue at the core. The articles included in this special section have been positioned in the map (see Figure 1) and are presented next.

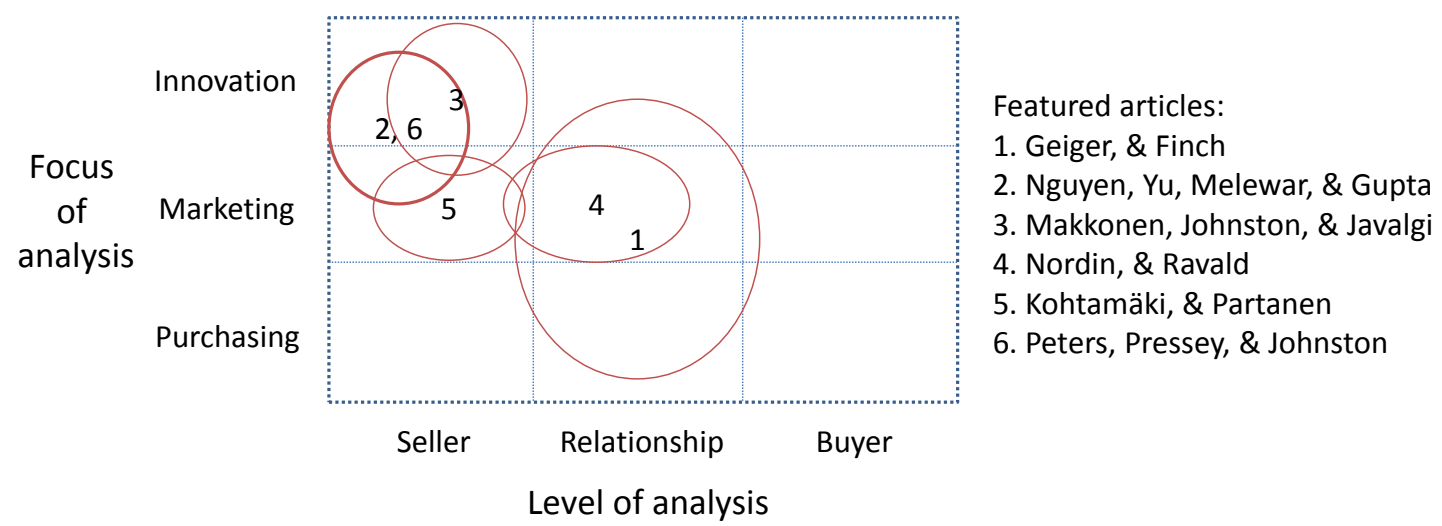

Figure 1. Business service research categories with different levels and focuses of analysis

To start, Geiger and Finch ("Making Incremental Innovation Tradable in Industrial Service Settings") analyze how organizations develop, buy, and sell incremental innovation as a service. Recognizing that the locus of interaction in many knowledge-intensive business services has shifted from stable and discrete offerings to rather nebulous concepts such as problem solving and innovation, they discuss tensions and conflicts that can take root in these exchanges as a result of this change. Combining a longitudinal study of a chemical services firm with literature on industrial services and Galison's (1999) concept of a trading zone, they assess how actors offer, value, and exchange such innovations. The unit of analysis is exchanges, which are connected to incremental innovation across groups within the firm and when buying, selling, and exploited across organizational boundaries. The findings are based on the interactions between 
communities (technical, sales, and customers) across seven different projects as well as on observations. The article describes three empirical themes: formatting incremental innovation as a service; coordinating exchanges of incremental innovation; and resolving value conflicts. The authors find that trading zones complement relational processes and contractual arrangements by allowing parties to preserve their own logics and innovation expertise, and they postulate four propositions. In terms of practical implications, trading zones may put pressure on marketers and procurers to define their exchanges in terms of benefits rather than with technical vocabulary. The emphasis on exchange complements the concepts of relationships and networks by focusing on how relational contexts are intertwined with episodes of exchange (Holmlund, 2008).

In their study, Ngyen, Yu, Melewar, and Gupta ("Critical Brand Innovation Factors (CBIF): Understanding Innovation and Market Performance in the Chinese High-Tech Service Industry") develop and test a model of critical brand innovation factors that integrates four key variables in business service markets: innovation, internationalization, market orientation, and organizational learning. Their findings from a survey in China demonstrate that when brands are more innovative, their performance increases and that brand innovation plays a fully mediating role on the effects of market orientation and organizational learning for market performance. They furthermore find that a lack of innovation reduces market performance even when internationalization, market orientation, and organizational learning are present. In a high-tech industrial services context, the study is able to show empirical support for a positive link between market orientation and innovation and demonstrate that market orientation is a critical factor for brand innovation and a firm's innovativeness. Findings additionally suggest that a superior market performance requires not only information on customers but also proactive implementation of innovative activities such as organizational learning, orientation toward 
markets, and internationalization efforts. The study contributes to academic knowledge about brand innovation capabilities in high-tech industrial companies and can be useful for managers of service firms aiming to internationalize.

The third article, by Makkonen, Johnston, and Javalgi ("A Behavioral Approach to Organizational Innovation Adoption"), applies a customer-dominant logic lens to the organizational adoption context to provide a behavioral approach on organizational innovation adoption. The lens of customer-dominant logic (Heinonen \& Strandvik, 2015) and the notion of customer needing (Strandvik, Holmlund, \& Edvardsson, 2012) are used to conceptualize organizational innovation adoption behavior in terms of the activities undertaken to identify, evaluate, and match potential needs and solutions and implement the resulting need-solution coupling in company practices. Four qualitative cases in an in-depth, longitudinal qualitative field study are examined. The analysis shows how the interplay between these activities and the elements comprise micro-foundations of organizational innovation adoption behavior and provide an opportunity to typify different adopter profiles. The study typifies the focal adopter companies as Builder, Bureaucrat, Downhiller, and Sniper. The findings suggest that the management of adoption of innovation is about facilitating the constant questioning of current performance and routines; supporting the process of identifying potential needs and solutions; matching the solutions with the needs; and deciding on the best-fitting need-solution couplings for implementation.

Nordin and Ravald ("Managing Relationship Gaps: A Practitioner Perspective”) adopt a practice-based research approach to explain empirical findings drawn from industrial service contexts and contribute an explanatory framework of how practitioners handle relationship gaps in practice and what factors guide and shape their behaviors. They describe relationship gaps as 
situations in which the interests of the parties in the relationship no longer match, such as when a supplier shifts from a product-based business logic to a service-based one. They find that current relationship management seems to lack a "practical touch" in explaining managers' behaviors and set out to analyze work-life stories from practitioners with a strategy-as-practice research approach. Six industrial companies participated in the long-term project, and the continuous refining of the developed framework in close cooperation with practitioners added robustness to the findings and conclusions. The findings provide labels and meanings for what is done to manage relationship gaps in terms of behaviors (complaisant/persistent), activities (e.g., dramatizing, reconciling, circumventing, refusing), and influencing factors (perceived validity/feasibility). With its strategy-as-practice approach and research design (Vaara \& Whittington, 2012), the study responds to calls for more bottom-up empirical research into how marketing is actually done in organizations.

In the fifth contribution, Kohtamäki and Partanen ("Co-creating Value from KnowledgeIntensive Business Services in Manufacturing Firms: The Moderating Role of Relationship Learning") analyze the moderating role of relationship learning in the relation between industrial services, specifically knowledge-intensive business services, and customer-specific sales performance. The study adopts the view of Selnes and Sallis (2003) on relationship learning, which they define as "a joint activity between a supplier and a customer in which the two parties share information, which is then jointly interpreted and integrated into a shared relationshipdomain specific memory" (p. 80). In order to test the hypothesis, a survey of supplier-customer relationships in the Finnish machine and equipment manufacturing industry was conducted. The study finds that the co-creation of value from industrial services requires relationship learning. The findings also suggest that the relationship between industrial services and sales performance 
is linear, with a moderating role of relationship learning. This finding contradicts other studies on the financial impact of industrial services that stipulate a U-shaped relationship between service provision and performance. The authors suggest that this finding may be explained by the context of the study and the characteristics of its sample.

Finally, Peters, Pressey, and Johnston (“Contingent Factors Affecting Network Learning") examine how two contingency factors of absorptive capacity—power relationships and social integration mechanisms - influence how members in temporary organizational networks engage in, and benefit from, learning. Shared cognitions and sensemaking are not seen simply as mental processes but as processes that can facilitate learning and guide behavior. By utilizing cognitive consistency and sensemaking theory, the authors develop a framework for learning processes in organizational networks. With two case studies of design teams in the U.K. construction industry, this contribution identifies a number of practical ways in which firms can facilitate organizational learning in temporary organizations. The study postulates that the development of social capital through personal and structural power relations influences the extent to which learning takes place in the organizational network. Furthermore, if the use of social integration mechanisms allows the development of shared cognitions between organizational members, then learning will be positively affected. This influence is attributed to the greater cognitive consistency within the organization that such mechanisms enable.

\section{An Agenda for Academic Inquiry}

Despite the growing body of research on organizational behavior in business service contexts in the business and management literatures (e.g., marketing, innovation, operations, and technology management), many issues still await attention from researchers. One explanation for 
this knowledge gap, we suggest, is that the relationship between innovation, marketing, and purchasing is richer and more complex than any one literature suggests. First of all, we would like to highlight the buyer perspective; that is, the other side of the coin that tends, as in this special section, to receive less attention. Service sourcing and service outsourcing are examples of broad topics with company relevance in need of scrutiny in marketing and business management. They have been researched to some extent in the supply chain and operations management streams of literatures but these studies are rather disconnected from marketing studies. An example of an undoubtedly company-relevant issue in the service sourcing context that has emerged recently is service triads; that is, when services are purchased by one organization from another, but delivered to a third party - the customer (Nordin, Brozovic, \& Holmlund, 2013; Wynstra, Spring, \& Shoenherr, 2015). Triad situations are becoming more and more common because of the outsourcing trend, but they seem not yet to have been noted, given the dearth of published scientific knowhow and new management tools related to outsourcing and offshoring. Furthermore, studies of service-led growth in industrial contexts (i.e., service infusion and servitization) often focus on the manufacturer and customer but omit service partners as critical actors. For example, companies need to develop relationships with users of their equipment as well as with dealers that sell and service that equipment (Kowalkowski, Kindström, \& Carlborg, in press). Increasing the number of involved companies to a network or market level comes with new challenges and represents a new context in which business service should be explored.

Second, also with an obvious company relevance (and outside the themes of the selected papers for this special section), we would like to remind researchers about financial issues related to business services. Although a growing number of studies investigate links between 
business services and financial performance (e.g., Eggert, Hogreve, Ulaga, \& Muenkhoff, 2014; Kwak \& Kim, 2016), there are still, unfortunately, relatively few such empirical and conceptual studies. There is undeniably a need for them and there should be ample possibilities to link interests with companies and researchers from the financial and accounting disciplines to increase knowledge and improve business as a result. Better understanding and managing of, for example, pricing, revenues, costs, profitability, return on investment, and productivity in relation to business services is essential. However, although more effort is needed in the process of theory generation, we should also encourage replication research. As Easley, Madden, and Dunn (2000) point out, marketing research lacks a replication tradition, which may also be the case in other business disciplines. Fostering a replication tradition in research may actually advance theory development and refinement.

Third, in a similar vein and more broadly speaking, management, leadership, and decision-making in business service companies and during the transition to service orientation in product-centric firms pose many challenges for managers that more researchers could tap into. This special section includes papers on learning, absorptive capacity, and knowledge transfer, tensions that reveal ample theoretical and managerial challenges. So-called dark sides and the management of negative issues also offer possibilities for researchers and managers alike.

As a fourth suggestion for further explorations in business services, we highlight the significance of sustainability, social responsibility, and environmental considerations. Although research on these issues is gaining ground in business and management literatures (e.g., Alhouti, Johnson, \& Holloway, 2016), few studies have combined such issues for business services, exploring their impact, practices, management, and evaluation. Recent attempts to conceptualize the integration of economic and environmental viability in a sustainable way, such as the closed- 
loop concept of circular economy (Murray, Skene, \& Haynes, 2015), could thus be one of the research avenues ahead.

\section{Conclusions}

This special section contains papers on the selected industrial service context that cover different issues related primarily to innovation but also to marketing. It provides a good mix of papers that deal with issues ranging from relationship management, innovation adoption, and network learning to branding in the Chinese market. The papers also represent a combination of qualitative and quantitative methodologies and empirical and conceptual research. We hope that business researchers and organizational practitioners enjoy perusing this work and will be able to find novel and interesting ideas and tools for conducting future research and developing their service businesses.

\section{Acknowledgments}

We want to acknowledge our fellow researchers who have helped us with our special section. We first extend our thanks to all researchers who submitted their manuscripts for consideration. The submissions clearly showed a great amount of inspiring and valuable research related to the selected topics that will contribute to academic research as well as managerial practice. Not all of the papers could be published here, but we are looking forward to seeing the papers published elsewhere soon. We also extend our warmest thanks to our skilled professional reviewers, who come from more or less all countries where relevant research is being conducted. This special section would not have been possible without the supportive contributions of the 
reviewers, who invested substantial time, effort, and knowledge in reviewing manuscripts. Our professional reviewers (in alphabetical order) are as follows:

- Leena Aarikka-Stenroos (Tampere University of Technology, Finland)

- Per Andersson (Stockholm School of Economics, Sweden)

- Galina Biedenbach (Umeå School of Business and Economics, Sweden)

- Anne-Sophie Binninger (Reims Management School, France)

- Keith Blois (Independent Education Management Professional, UK)

- Ross Brennan (University of Hertfordshire, UK)

- Chiara Cantù (Università Cattolica del Sacro Cuore, Italy)

- John Finch (Adam Smith Business School, University of Glasgow, UK)

- Gary Frankwick (University of Texas at El Paso, USA)

- Susi Geiger (University College Dublin, Ireland)

- Christian Grönroos (Hanken School of Economics, Finland)

- Suraksha Gupta (Kent Business School, UK)

- Anders Gustafsson (Karlstad University, Sweden)

- Francisco Guzmán (University of North Texas, USA)

- Fredrik Hacklin (ETH Zurich, Switzerland)

- Aino Halinen (University of Turku, Finland)

- Anu Helkkula (Hanken School of Economics, Finland)

- Anne-Maria Holma (University of Vaasa, Finland)

- Kajsa Hulthén (Chalmers University of Technology, Sweden)

- Elina Jaakkola (University of Turku, Finland)

- Raj Javalgi (Cleveland State University, USA) 
- Sören Kock (Hanken School of Economics, Finland)

- Marko Kohtamäki (University of Vaasa, Finland)

- Catharina von Koskull (University of Vaasa, Finland)

- Gyöngyi Kovacs (Hanken School of Economics, Finland)

- Hannu Makkonen (University of Turku, Finland)

- Katy Mason (Lancaster University, UK)

- Stefanos Mouzas (Lancaster University, UK)

- Suvi Nenonen (University of Auckland, New Zealand)

- Fredrik Nordin (Stockholm University, Sweden)

- Aron O'Cass (University of Tasmania, Australia)

- Eleonora Pantano (Middlesex University, UK)

- Jukka Partanen (Aalto University, Finland)

- Audhesh Paswan (University of North Texas, USA)

- Linda Peters (Nottingham University, UK)

- Andrew D. Pressey (University of Birmingham, UK)

- Edward Ramirez (University of Texas at El Paso, USA)

- Arto Rajala (University of Vaasa, Finland)

- Annika Ravald (Hanken School of Economics, Finland)

- Jonathan Reynolds (University of Oxford, UK)

- Thomas Ritter (Copenhagen Business School, Denmark)

- Martin Spring (Lancaster University, UK)

- Maria Sääksjärvi (Delft University of Technology, The Netherlands)

- David Sörhammar (Uppsala University, Sweden) 
- Harry Timmermans (Eindhoven University of Technology, The Netherlands)

- Marja Toivonen (VTT Technical Research Centre, Finland)

- Zsofia Toth (Nottingham University, UK)

- Bård Tronvoll (Hedmark University College, Norway)

- Alessandra Tzannis (Università Cattolica del Sacro Cuore, Italy)

- Jaana Tähtinen (University of Turku, Finland)

- Lars Witell (Linköping University, Sweden)

- En Xie (Xi'an Jiaotong University, China)

- Xiaoyu Yu (Shanghai University, China)

- Judy Zolkiewski (University of Manchester, UK)

Finally, we are grateful to the Editor-in-chief of Journal of Business Research, Arch Woodside, for supporting us and our special section, Organizational Behavior in Innovation, Marketing, and Purchasing in Business Service Contexts. 


\section{References}

Alhouti, S., Johnson, C. M., \& Holloway, B. B. (2016). Corporate social responsibility authenticity: Investigating its antecedents and outcomes. Journal of Business Research, $69,1242-1249$.

Brennan, R., Tzempelikos, N., \& Wilson, J. (2014). Improving relevance in B2B research: Analysis and recommendations. Journal of Business \& Industrial Marketing, 29, 601609.

Cyert, R. M., \& March, J. G. (1963). A behavioral theory of the firm. Englewood Cliffs, NJ: Prentice Hall.

Davies, A. (2004). Moving base into high-value integrated solutions: A value stream approach. Industrial and Corporate Change, 13, 727-756.

Easley, R. W., Madden, C. S., \& Dunn, M. G. (2000), Conducting marketing science: The role of replication in the research process. Journal of Business Research, 48, 83-92.

Eggert, A., Hogreve, J., Ulaga, W., \& Muenkhoff, E. (2014). Revenue and profit implications of industrial service strategies. Journal of Service Research, 17, 1723-39.

Galison, P. (1999). Trading zone: Coordinating action and belief. The Science Studies Reader, $13,137-160$.

Gebauer, H., Fleisch, E., \& Friedli, T. (2005). Overcoming the service paradox in manufacturing companies. European Management Journal, 23, 14-26.

Gebauer, H., Gustafsson, A., \& Witell, L. (2011). Competitive advantage through service differentiation by manufacturing companies. Journal of Business Research, 64, 12701280. 
Grönroos, C., \& Ojasalo, K. (2004). Service productivity: Towards a conceptualization of the transformation of inputs into economic results in services. Journal of Business Research, $57,414-423$.

Grönroos, C., \& Voima, P. (2013). Critical service logic: Making sense of value creation and cocreation. Journal of the Academy of Marketing Science, 41, 133-150.

Gustafsson, A., Brax, S., \& Witell, L. (2010). Setting a research agenda for service business in manufacturing industries. Journal of Service Management, 21, 557-563.

Gustafsson, A., Aksoy, L., Brady, M. K., McColl-Kennedy, J. R., Sirianni, N. J., Witell, L., \& Wuenderlich, N. V. (2015). Conducting service research that matters. Journal of Services Marketing, 29, 425-429.

Heinonen, K., \& Strandvik, T. (2015). Customer-dominant logic: Foundations and implications. Journal of Services Marketing, 29, 472-484.

Henneberg, S. C., Gruber, T., \& Naudé, P. (2013). Services networks: Concept and research agenda. Industrial Marketing Management, 42, 3-8.

Holmlund, M. (2008). A definition, model, and empirical analysis of business-to-business relationship quality. International Journal of Service Industry Management, 19, 32-62.

Ivens, B. S., Pardo, C., \& Tunisini, A. (2009). Organizing and integrating marketing and purchasing in business markets: An introduction to the special issue, issues and implications. Industrial Marketing Management, 38, 851-856.

Jacob, F., \& Ulaga, W. (2008). The transition from product to service in business markets: An agenda for academic inquiry. Industrial Marketing Management, 37, 247-253.

Jaworski, B. J. (2011). On managerial relevance. Journal of Marketing, 75, 211-224. 
Kim, S. H., \& Huarng, K. H. (2011). Winning strategies for innovation and high-technology products management. Journal of Business Research, 64, 1147-1150.

Kindström, D., \& Kowalkowski, C. (2014). Editorial: Service innovation in business-to-business firms. Journal of Business \& Industrial Marketing, 29, 93-95.

Kindström, D., Kowalkowski, C., \& Sandberg, E. (2013). Enabling service innovation: A dynamic capabilities approach. Journal of Business Research, 66, 1063-1073.

Kowalkowski, C. (2015). Business marketing: A Nordic School perspective. In J. Gummerus \& C. von Koskull (Eds.), The Nordic School - Service marketing and management for the future (pp. 55-67). Helsinki, Finland: Hanken School of Economics. Retrieved from https:/helda.helsinki.fi/handle/10138/156531.

Kowalkowski, C., Kindström, D., Brashear, T. A., Brege, S., \& Biggemann, S. (2012). Service infusion as agile incrementalism in action. Journal of Business Research, 65, 765-772.

Kowalkowski, C., Kindström, D., \& Carlborg, P. (in press). Triadic value propositions: When it takes more than two to tango. Service Science.

Kwak, K, \& Kim, W. (2016). Effect of service integration strategy on industrial firm performance. Journal of Service Management, 27, EarlyCite.

Lieberman, M. B., \& Montgomery, D. B. (1988). First-mover advantages. Strategic Management Journal, 9, 41-58.

Lindgreen, A., Campelo, A., \& Angell, R. (in press). Introduction to the special issue on Comanagement of Purchasing and Marketing. Industrial Marketing Management.

Möller, K., \& Parvinen, P. (2015). An impact-oriented implementation approach in business marketing research: Introduction to the Special Issue on "Implementing Strategies and 
Theories of B2B Marketing and Sales Management." Industrial Marketing Management, $45,3-11$.

Murray, A., Skene, K., \& Haynes, K. (2015). The circular economy: An interdisciplinary exploration of the concept and application in a global context. Journal of Business Ethics, 1, 1-12.

Neely, A., Ng, I., \& Roy, R. (2014). Complex engineering service systems. Journal of Service Management, 25, 572-573

Ngo, L. V., \& O’Cass, A. (2013). Innovation and business success: The mediating role of customer participation. Journal of Business Research, 66, 1134-1142.

Nordin, F., Brozovic, D., \& Holmlund, M. (2013). Disintermediation in business-to-business service channels: Mechanisms and challenges. Journal of Business-to-Business Marketing, 20, 179-192.

Ostrom, A. L., Parasuraman, A., Bowen, D. E., Patrício, L., Voss, C. A., \& Lemon, K. (2015). Service research priorities in a rapidly changing context. Journal of Service Research, $18,127-159$.

Piercy, N. F. (2002). Research in marketing: Teasing with trivia or risking relevance?. European Journal of Marketing, 36, 350-363.

Selnes, F., \& Sallis, J. (2003). Promoting relationship learning. Journal of Marketing, 67, 80-95.

Sheth, J. N., Sharma, A., \& Iyer, G.R. (2009). Why integrating purchasing with marketing is both inevitable and beneficial. Industrial Marketing Management, 38, 865-871.

Strandvik, T., Holmlund, M., \& Edvardsson, B. (2012). Customer needing: A challenge for the seller offering. Journal of Business \& Industrial Marketing, 27, 132-141. 
Ulaga, W., \& Reinartz, W. (2011). Hybrid offerings: How manufacturing firms combine goods and services successfully. Journal of Marketing, 75, 5-23.

Vaara, E., \& Whittington, R. (2012). Strategy-as-practice: Taking social practices seriously. The Academy of Management Annals, 6, 285-336.

Van de Ven, A. H. (2007). Engaged scholarship: a guide for organizational and social research: a guide for organizational and social research. OUP Oxford.

Vargo, S. L., \& Lusch, R. F. (2004). Evolving to a new dominant logic for marketing. Journal of Marketing, 68, 1-17.

Wagner, S. M., \& Eggert, A. (in press). Co-management of purchasing and marketing: Why, when and how? Industrial Marketing Management.

Wiersema, F. (2013). The B2B Agenda: The current state of B2B marketing and a look ahead. Industrial Marketing Management, 42, 470-488.

Wirtz, J., Tuzovic, S., \& Ehret, M. (2015). Global business services: Increasing specialization and integration of the world economy as drivers of economic growth. Journal of Service Management, 26, 565-587.

Wynstra, F., Spring, M., \& Schoenherr, T. (2015). Service triads: A research agenda for buyersupplier-customer triads in business services. Journal of Operations Management, 35, 120.

Yadav, M. S. (2010). The decline of conceptual articles and implications for knowledge development. Journal of Marketing, 74, 1-19. 